\title{
Identity of Muslim in Thailand Guese Study Muslim Shi’ah in Thonburi Bangkok
}

\author{
${ }^{1}$ Mr Vichit Vichaisarn, ${ }^{2}$ Dr Prasert Suksaskawin \\ ${ }^{1}$ Dean of management Science Faculty \\ ${ }^{2}$ Eastern Asia University,Pathumthani,Thailand
}

\begin{abstract}
Doing this research The purpose is to learn the identity of Muslims in Thailand: A Case Study of Muslim Shia sect, Thonburi, Bangkok. And to study the living conditions of the Muslim Shia sect, Thonburi, Bangkok, qualitative research methods. The study indicated that Identities of Muslims in Thailand: A Case Study of Muslim Shia sect, Thonburi, Bangkok overall unity and identity as Shia Muslim sects are strong. The last ceremony of Ashura or "ceremony Centaur" and considering that each side. In all aspects

This research aims.(1) To determine the identity of the Shia Muslim sect, Thonburi, Bangkok.(2) study the expectations of the Shia Muslim sects to maintain the identity of the Shia Muslim sect, Thonburi, Bangkok.The research found that(1) the identity Mugabe's Shia sect wind Thonburi, Bangkok. Summarized as follows 1. The philosophy and the core teachings, beliefs and practices of the religious sect of Shia. Overall, it is in the middle. 2. Participation in religious ceremonies by the Shia sect. Found that there are lots and at a high level.3. To preserve the culture and identity as Shia. The signing ceremony Held at high level(2) the expectations of the Shia Muslim sects to maintain the identity of the Shia sect, Thonburi, Bangkok. Summarized as follows2.1 The religious leaders showed that the overall level.2.2 Executive religious organizations as a whole were at a high level.2.3 Shia Muslim people as a whole were at a high level.
\end{abstract}

Keyword: Muslim identity Study

\section{Introduction}

Thailand society from the past until now a multicultural society. The existence of diverse cultures, languages and religious beliefs. And ethnic groups on the other and Thailand The Thailand Muslims into Thailand was the difference in the race, that is in addition to the races, Thailand was also hit by an ancestor of the different races is to call the ancestors. Persian, Arabic, Javanese - Malay Cham - Cambodia, India, Pakistan, Bangladesh and China.

The Muslims who are ethnically different if such a distinction in the history of political ideas. Also divided into two groups, two academic groups called sect is Shia and Sunnah.Shia Muslim community in Bangkok late in the Thon Buri. Line Shia Muslim community has its own mosque. Because Shiites, who is descended from Ahmad Gummi You just have this community adjacent to the Sunni sect of Muslims. The canal is Bangluang Gudi or Tonson Mosque Therefore, the religious establishment is generally good. Ministry for the month of Muharram Shia Muslim, but Shia mosque to celebrate the pines. This includes Kubo, who was at the funeral, shared. The prince Sheikhul Islam, which is a Shia, but the Ayutthaya period of 13 he was the Shia Muslims. And funeral of Prince Chula since five people were buried in Kubo's Tonson Mosque. 
In some areas along the canal royal road of independence on both sides. Bridge since succeeding Phat is a huge community of Shia Muslims. The mosque is a mosque consists of three clay Saif Salah Plaina or monk. Mosque openness theology behind Kudi Charoen Phat. And Kudi Charoen Phat located opposite the tomb Plaina is generally known, but the former monastery. Built during the reign of King Rama skyline. The use of religious activity And in the month of Muharram rituals that appear in the paper. "The Sacred Ram" Rama II of Rattanakosin products. The sequel to the present

Shia Muslims, a similar line of Ahmad settled in the area of the mosque, and later extended to the contact, Bangkok. Including district Bangnamprieo Chachoengsao And Bang later. Shia Muslims still carry on the tradition as well as in Thailand. "The signing ceremony," which was done in the first 10 days of the month of Muharram. To commemorate the tragedy of slain Imam Hussein Allah (district) their love of the Prophet Muhammad (pbuh) who was killed brutally by an enemy of Islam, along with the sons of. Las Vegas plate of noodles in Iraq. Today

Current Shia descended from just a bunch Spirit has Mosques ordinances together consisting of 7 mosque Adil Saif Salah. Mosques uphold fair Mosques Imam Allah Great Bay (monk Luang) Monk (Hussein's Allah) Charoen Phat Mosque Al-Hussein's (Chan) Hussein but Allah Mubarak Bull Haim. the baby Mosques and imams Software Nordic (district) Bangnamprieo Chachoengsao.

Community District Thonburi side of Bangkok, a cultural area (cultural area) One of the differences and diversity. The dimensions of a nation or ethnicity (ethnic group) and the dimension of religion, with such a difference in Islam between Sunni (sunni) and sectarian Shia (shi ite) distinction of Christians during Roman Catholic denominational pro. each instance And both Mahayana and Theravada Buddhism in Thailand. The researchers studied a group of guests that you sign in Thonburi on the ethnic issue. Including a sect of Shia Islam. The rituals of this group called "The signing ceremony"

\section{Objective}

- One to study the identity of the Shia Muslim sect, Thonburi, Bangkok.

- to study the expectations of the Shia Muslim sects to maintain the identity of the Shia Muslim sect, Thonburi, Bangkok.

- $\quad$ to understand the society and culture of the Muslim Shia sect by the study.

\section{Benefits Are Expected to Receive.}

- The signing ceremony was first understood as the cultural identity of the Muslim Shia sect.

- puts you into signing ceremony as a ritual for the maintenance of the Shia Muslim community in Thailand.

- can output a study that compared with the other groups in society in terms of maintenance with their identities.

\section{The Resolution of the Study}

The signing ceremony took place in Thailand. Have come with a group of people with ethnic communities, dating from the Ayutthaya period. In fact, the role of such rituals. Find the identity of a people who express a specific ethnic pogroms. It refers to the implications of the ethnic identity of the people who share it. This means covering the Arab and Persian, Indian or other ethnic groups, it is not. This is because the ethnic identity is seen through this ritual represents the realization of a people or a people who treat each other's culture. Yes, by the purity of the ethnic minorities of any kind. It also has a role in a variety of ethnic identities that have the same or similar thing in consciousness. Is an ethnic Muslim Shia sect to remain in Thailand amid social change over time until the present. 


\section{Area of research}

The research was limited to the area of Shia Muslim community in Thonburi. Both past and present, including four areas Kudi Kudi Charoen Phat Plaina monk Luang Mosque and sustained fairly, Thonburi, Bangkok.

\section{Steps to Study}

- One study and gathering of all documents related to the history of the Shia Muslim community in Thailand. Especially guests Centaur The signing ceremony

- two educational theories and adopt a framework and guidelines for the study.

- field studies by means of the National Federation of Hannah. (Ethnography) for collecting data based on the needs of the community. Especially about the history, culture, traditions and rituals with no formal interview. Including participant observation (participant observation).

- Verify the accuracy of the information. The compilation, analysis, and discussion

\section{Research Result}

The results of the study and research on the identity of Muslims in Thailand: A Case Study of Muslim Shia sect, Thonburi, Bangkok. In keeping Mugabe's identity wind Shia sect. Summarized as follows

- Understanding the core philosophical doctrines and ordinances.

- philosophy and the core teachings, beliefs and practices of the religious sect of Shia. Overall, it is in the middle.

- The understanding of the religious sect by Shia. Found that there are lots and at a high level.

- of preserving culture and identity as Shia. Through the month of Muharram rituals. Day of Ashura (Centaur ceremony) held at a high level.

Expectations of Shia Muslim sects to maintain the identity of the Shia sect, Thonburi, Bangkok.

- The religious leaders showed that the overall level.

- $\quad$ Executive religious organizations as a whole were at a high level.

- Shia Muslim people as a whole were at a high level.

\section{References}

[1] William, Holloway V. (1951). State and Local Government in The Unistates. New York: McGraw Hill.

[2] William A. Robson. (1953.) Local Govemment. Encyclopaedia of Social Science. Vol.x. New York :The Macmillan Co..)

[3] Daniel. Wit. (1967).A Comparative Sursey of Local Government and Administration. Bangkok :

[4] Kurusapha Kanjanacnaraks (1992), Curriculum Deverlopment, 2nd edition Genesis: Printing Silpakorn University

[5] KriengsakChareonwongsak (2000), South wise Educators, Edition 4: A blockade net Dhaka printing.

[6] Religious Affairs (1992), Registration mosque in Thailand, The degree Snoopy Waithayopathum,Bangkok 